\title{
Police Prevention Units in Poland from 1918 to Modern Times
}

\author{
Robert Czerniawski ${ }^{1}$ \\ ${ }^{1}$ Department of Internal Security, the Police Academy in Szczytno \\ st. Marszatka Józefa Pitsudskiego 111, 12-100 Szczytno - Poland
}

\begin{abstract}
The police forces are an indispensable element in upholding security and public order in a state, both on daily bases and in states of emergency. The evolution of the Polish police forces begins in 1918 with restoration of the country's sovereignty after 123 years of partitions. Since that time the organisational structure, functioning and the scope of tasks performed by the Police have evolved and developed due to social, political and economical changes in order to keep up with constantly changing reality and to improve efficiency of operations performed with respect to maintaining security and public order.
\end{abstract}

Index Terms - the Police, security, preventive anti-riot units, police tasks.

\section{INTRODUCTION}

Poland regained its independence in 1918, however the process of reuniting all territories took some time before the final shape of the borders of the Second Polish Republic was determined. The core of the re-born state was the area of the Kingdom of Poland. The creation of a modern centralised formation responsible for upholding security and public order took a great deal of effort from politicians, social activists and civic institutions (Marszałek, 2009). As early as on 22 July 1919 a draft of the act, most probably prepared by the Ministry of Interior, was submitted to the Sejm. Despite numerous objections from the right wing and people's party MPs, as well as from ethnic minorities, the Act on the National Police was passed on 24 July 1919 (Misiuk, 1998). The National Police was built upon the already existing Security Police which consisted of the People's Police and the Municipal Police and was a state security organisation, whose main task was to protect security and public order, and to act as the executive organ for central and local authorities (Misiuk, 2008).

After 1919 the newly created Police forces were reorganised, extended, developed and perfected. Officers underwent a series of professional and specialist courses. For the first time women were admitted into professional training for police officers. In

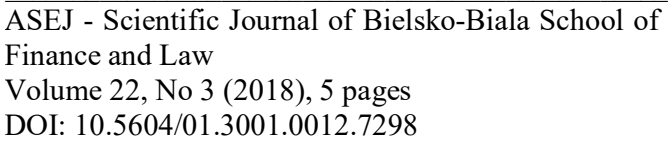

Received 03 September 2018; Accepted 17 September 2018 years that followed, regular police academies were founded. The fastest pace of development of the police education system in Poland could be observed after the May Coup d'Etat, when the first academies for officers and privates were established. The best students were sent abroad to be educated in prestigious police training centres all over the world. In 1939 the police education in Poland was on a high European level (Misiuk, 1998).

At the end of WWII the National Council of Ministers issued a resolution pursuant to which on 1 August 1944 local government guards and security corps were created on the liberated territories of Poland. The security corps was the executive organ of the government and was used for maintaining public order, coordination, support and supervision of local guards which were established in communes and municipalities (Majer, 2004).

The next stage of transformations of law enforcement agencies in Poland was the creation of the Citizens' Militia. The guidelines which had been formulated in the PKWN Manifesto of 22 July 1944, and brought to life by a PKWN decree of 7 October 1944, established the Citizens' Militia (MO) as a legal and public organ subjugated to the public security service (Misiuk, 2008). After 1944, the Citizens' Militia was mainly used for political purposes such as the fight with opposition and enemies of state. Combating crime and enforcing security and public order was not in the centre of attention of this particular service, although officially, pursuant to a decree of December 1944, MO was supposed to uphold public security, protect peace, public order, life and health of citizens, common and individual property, counteract crime and conduct preparatory operations.

The structures of the Citizens' Militia (MO) included a unit called ORMO (Voluntary Reserves of the Citizens' Militia) which was a paramilitary voluntary people's organisation established in 1946. ORMO was assisting the Citizens' Militia and was organisationally subjugated to the Polish Workers' Party (PPR) and later its successor the Polish United Workers' Party (PZPR). Upon decision of Władysław Gomułka in 1956,

Regular research paper: Published 15 October 2018

Corresponding author's e-mail: robertcze1@o2.p1

Copyright $(\subset 2018$ This is an open access article distributed under the Creative Commons Attribution CC-BY-NC 4.0 License. 
a special anti-riot task force, the so called ZOMO (Motorized Reserves of the Citizens' Militia) was created. ZOMO functionaries were supposed to undertake preventive activities during waves of social unrest, protests and demonstrations. MO and ZOMO units took part in suppression of students protests during the Political Crisis in March 1968, they pacified workers' strikes and protests that spread in 1970 along the Polish coastline, and in 1981 during martial law they were crucial in extinguishing a wave of mass social unrest and in detaining the leaders of the Solidarity movement.

The year 1989 was a breakthrough year. The social, economic and political revolution in Central and Eastern Europe, including Poland, brought about the necessity for reforms in uniformed agencies responsible for security and public order. The Act on the Police of 6 April 1990 dramatically changed the role and functions of law enforcement services. The highly politicized and anti-social Citizens' Militia was dissolved and replaced by a citizen friendly formation focused on protection of security and public order. The Act on the Police of 1990 contained organisational and functional guidelines for the new Police, it also stipulated the rights and duties of police officers. The head of the new Police forces came to be known as the Commander in Chief - a public administration officer responsible for protection of citizens and public order. Local government organs were given the right to evaluate and give opinions, appoint and remove local commanders in chief, request reports, information and explanations related to the execution of service duties by police officers.

\section{PREVENTION UNITS OF THE NATIONAL POLICE IN THE INTERWAR PERIOD}

In the interwar period, the ruling administration used preventive anti-riots units of the Military Police for emergency situations which posed a threat to public security. The armed forces efficiently applied power play to solve social conflicts, disperse protests, rallies, manifestations and marches. In case of particularly violent riots the army was allowed to use firearms upon express request of the authorities on the condition that the commander of the relevant military unit agreed that it was fully justified. Article 23 of a decree of 2 January 1919 on military interventions in emergency situations, specified when firearms could be used. However, units of infantry and cavalry, frequently used to disperse crowds from squares and streets, usually managed to restore peace without the need to fire a single bullet. The Constitution of 17 March 1921 allowed military intervention under strict compliance with relevant acts on quelling riots or compulsory enforcement of the legal provisions. Exceptions to this rule were only permitted pursuant to the Act on the Emergency and Martial Law - article 123 of the Act.

In the Second Polish Republic if the Police forces failed to restore internal security of the state, the army often took over since it disposed of qualified soldiers and adequate equipment to resolve any social or political conflict by use of force and in no time at all. The army was used for instance in August 1921 to put an end to a strike in the Grodno Power Plant; to disperse demonstrations after election of Gabriel Narutowicz for president of Poland and during parliamentary elections to the Sejm in autumn 1923 in Kraków (Sprengel, 2011).

Following mass protests of workers caused by poor social and economic situation in November 1923 in Kraków, Tarnów and Borysław, the central authorities established special preventive units, the so called 'school companies of the police reserves'. They were created on 5 December 1923 upon the decision of the Minister of Interior. Pursuant to the decision, the reserve companies were to enter into basic training for lower rank functionaries of the National Police, and should be in constant battle readiness. Such companies were formed in five different regions however, their training and education was far from professional. There were 60 men in each company equipped not only in standard but also in field equipment. In exceptional circumstances, upon consent of the Commander in Chief, these companies could be used in neighbouring regions in order to strengthen local police forces. Due to the Great Economic Crisis, the budget of the Ministry of Interior was considerably reduced, therefore after 1923 the development of 'the school companies of the police reserve' was put to a hold (Mączyński, 1997). It should be emphasized, however, that these companies were the predecessor of contemporary prevention units.

The idea of police reserve units used for prevention purposes was revived in the beginning of 1930s. The global economic crisis reached Poland and triggered some violent antiestablishment movements of the society frustrated by the worsening material situation. The government was forced to reestablish the reserve forces of the regular Police. In a resolution of 27 September 1932, the Minister of Interior of that time, Bronisław Pieracki, created a reserve of privates at the Main Headquarters of the National Police. The reserve, which was deployed and garrisoned in Żyrardów, was at the disposal of the Minister of Interior (Misiuk, 2008).

The poor economic and financial situation mentioned above, as well as high unemployment rate stirred anxiety and anger among workers and peasants (e.g. unrest began in Rzeszów, Mińsk Mazowiecki and many other towns, strikes of miners broke out in the regions of Dąbrowa Basin and Upper Silesia Basin, textile workers went on strike in Warsaw). To restore peace and extinguish strikes, regular officers of the National Police joined forces with the newly established reserve units.

Yet the wave of frustration among Polish workers intensified even further after 1935. As a response, the government formed more units of the Police reserve (Mączyński, 1997). President Ignacy Mościcki by a decree of 17 April 1936 amending the Act on the National Police, created the Preparatory Service of the National Police. The Preparatory Service was a police-military formation of preventive, anti-riot character (Misiuk, 2008) under command of the Minister of Interior. Members of the service were employed on contractual basis and were directed to special task forces. In the following month, the Minister of Interior, S. Składkowski, issued a resolution on conditions and functioning of the Preparatory Service which was to be garrisoned, uniformed, fed and paid regular wages (although much lower than regular officers) (Misiuk, 2008). The 
Preparatory Service was supposed to be in permanent combat readiness and in constant training to meet the requirements of the variety of tasks its functionaries were to perform. In spite of this, the functionaries were not full-time employees of the National Police forces. They worked on the basis of a contract which they signed upon entering the service. The contract obliged them to perform all service duties related to upholding security, peace and public order, especially when the forces of regular Police were inadequate to restore public order and quench resistance. In 1939 there were 13 reserve companies and 5 cavalry squadrons which were particularly effective in dispersing riots and demonstrations, especially during massive strikes, $1^{\text {st }}$ May demonstrations, pacifications of villages during peasants' strikes and during major events. The Preparatory Units were equipped in means of transport which guaranteed instant mobility whenever required. In the September Campaign of 1939, for the reasons unknown, these very-well organised police units were not incorporated in the system of resistance and did not undertake any combat operations.

\section{PREVENTION UNITS OF THE CITIZENS' MILITIA (MO) IN THE COMMUNIST ERA}

After WWII the security issues of the Polish People's Republic (PRL) landed in the hands of the communist authorities. The PKWN decree of 7 October 1944 brought to life the Citizens' Militia (MO), a formation which was supposed to uphold security and public order in the communist Poland. For a couple of years MO had not disposed of any special ant-riot preventive units. The first strike and wave of dissatisfaction among workers from the Cegielski Metal Works in Poznań were supressed on 28 June 1956 by combined effort of the Army and the Citizens' Militia, but the events showed that MO was not able to successfully handle mass protests (e.g. protests in Bydgoszcz and Szczecin in November 1956). In order to restore peace in emergency situations, the Council of Ministers of the Polish People's Republic issued a decree on 4 December 1956 which was the basis for creation of Motorized Reserves of the Citizens' Militia (ZOMO). The guidelines related to the service in $\mathrm{ZOMO}$ were introduced by an order of the MO Chief Commander general Dobiesz, issued on 17 July 1957. Pursuant to the order, ZOMO was a garrisoned paramilitary formation (Socha, Letkiewicz and Guła, 2010).

The first duty tasks entrusted to ZOMO were: safeguarding national elections to the Sejm (January 1957), and then violent quenching of people's demonstration in the village of Lutoryż near Rzeszów (March 1957). In July 1957, ZOMO suppressed a strike of tram drivers in Łódź and in October a demonstration of employees of a weekly newspaper in Warsaw. Gradually ZOMO functionaries were engaged in more and more numerous interventions. They were present wherever there was an outburst of dissatisfaction with the communist regime of the Polish People's Republic. They were in constant readiness, always in battle order. Originally the formation had been equipped with trancheons, batons and military helmets, later the equipment included also water cannons and tear gas launchers, as of the beginning of the 1960 s.
The Political Crisis of March1968 was triggered by university students in Warsaw who became angered by the censor's ban on the play 'Dziady' by Adam Mickiewicz in the National Theatre. The students took to the streets and the wave of demonstrations spread to Gdańsk, Kraków, Radom, Łódź and Poznań, but MO brutally quenched the riots. Around that time ZOMO once again had their equipment updated and modernised. The functionaries were uniformed in new 'moro' gears, they received protective shields and newer water cannons which were built upon the chassis of a popular heavy goods vehicle STAR. In 1983, ZOMO functionaries were clad in shin pads, better helmets, shock proof vests and disposed of five barrel tear gas grenade launchers, troop carriers equipped in battering rams or guarding fences, rubber bullet putters, metal gas grenades and even firearms. ZOMO became the best equipped and trained formation specializing in anti-riot interventions in the whole communist Europe. The recruits to the service had to be below 30 years of age, minimum $1,70 \mathrm{~cm}$ tall with clean criminal record, basic military training and at least primary school education. The main area of activity of ZOMO functionaries was dispersing and suppressing social protests, strikes, waves of political unrest, manifestations of the opposition etc. These tasks were performed with a great deal of brutality and inexorability. When required ZOMO functionaries may also have taken part in rescue activities during catastrophies or natural disasters, they searched for missing persons, escaped criminals and protected mass events. The Chief Commander, upon request from district commanders adjusted the headcount, organization and dislocation of units across the country (Socha, Letkiewicz and Guła, 2010). The number of functionaries initially at the level of 6,600 , rose to 30,000 at the end of $1980 \mathrm{~s}$. The biggest ZOMO unit was deployed in Golędzinów (the Warsaw district), but each major city in Poland also had one. During the martial law 1981-1983, units of MO and ZOMO were critical in pacification of strikes and protests.

There was yet another branch of the Citizens' Militia that must not be overlooked. The Voluntary Reserves of the Citizens' Militia (ORMO) were created following a resolution of the Council of Ministers on 21 February 1946. It was a paramilitary voluntary and social organisation supporting the MO (Majer, 2004). Originally the tasks to be performed by ORMO were limited to providing security during important social, cultural, sport or political events. However, in March 1968 the ruling communist party PZPR used ORMO to suppress students demonstrations. From that time ORMO directly reported to the District Security Commission and indirectly to PZPR. The MO Chief Commander in an instruction of 1 March 1946 described in detail specific tasks, organization, conditions for admission to the service, rules of the services as well as rights and duties (Majer, 2004). There were special task ORMO units deployed in each Polish district as well as the so called Road Traffic Brigades which were organised in factories. The ORMO units collaborated closely with ZOMO which was an inherent constituent of the communist apparatus of repression. ORMO co-protected mass events such as international football matches, festivals, 
manifestations and took part in the so called civic patrols hand in hand with the Citizens' Militia. ORMO was a uniformed formation without military ranks but each functionary carried a badge with distinctions of the performed function. ORMO uniforms were similar to field uniforms of infantry, the functionaries wore navy blue berets and when on an assignment they wore special helmets and carried batons and gas. As a rule ORMO functionaries did not carry firearms and they did not receive any wages for their service. The Road Traffic Brigades, in turn, supervised the flow of traffic but without the right to impose fines. During the Polish martial law the Brigades also engaged in political and propaganda activities. Pursuant to the decision of the MO Chief Commander of 3 February 1982, the Brigades were transformed into specialist units called the Political and Defense Units and with termination of the martial law they were dissolved by the Sejm in 1989.

With the end of communist era in Poland ZOMO units were dissolved on 7 September 1989 by a resolution of the Minister of the Interior who called it a negative and much hated symbol of the communist regime. They were substituted by the Prevention units of the Citizens' Militia, which in 1990 pursuant to the Act of 6 April 1990, were transformed into the Police Prevention Units.

\section{POLICE PREVENTION UNITS IN MODERN TIMES}

. After the political transformation of 1989, the Citizens' Militia was transformed into the Police and the Prevention Units of the Citizens' Militia were transformed into the Police Prevention Unit and Independent Police Prevention Units. Nowadays the main focus of the police activity in Poland is closely related to the notions of public security and public order. Police duties related to security include elimination of threats that may be posed by the ruling administration or other public organs and protection of life and health of citizens. Public order is connected with the necessity to eliminate any manifestations of unwanted acts that go against to what is viewed as appropriate in public space (Czapska, and Wójcikiewicz, 1999). The main form of police activity is prevention, within preventive activities a certain amount of repressive action is permissible e.g. during the process of restoring peace and order in case of demonstrations or riots provoked by hooligans at football stadiums. The anti-riot functionaries have at their disposal batons, tear gas and rubber bullets. Anti-terrorist units are entitled to use force and means of physical coercion including firearms (Jałoszyński and Zalewski, 2009). When riots do occur the units must safeguard the area of unrest not to allow the perpetrators to escape. Anti-riot police units report directly to Chief Commanders of the Police on voivodeship level.

The anti-riot preventive forces have a company structure which allows rapid reaction with considerable amount of strength. Detailed tasks and competences of anti-riot units include:

- upholding security and public order during legal gatherings and mass events;

- restoring public order in cases of collective violation of law;

- upholding security and public order during visits of heads of foreign states;

- upholding public order during emergencies, catastrophies and natural disasters provided for in the Constitution;

- supporting regular Police units in patrol and intervention activities;

- chasing dangerous criminals.

While on service duty, the anti-riot officers carry standard police equipment. In case of special tasks they are additionally equipped with protective helmets, shields, shock proof vests, nightsticks, shin pads, protective gloves, tear gas launchers, pepper gas launchers, tear grenades and flare pistols. They also use water cannons, automatic and manual tear grenade launchers as well as modern acoustic appliances.

Since1989, the National Police has been a service friendly to the citizen. In a democratic state it is important to provide expected level of security to the citizens and protect the fair standards of living.

\section{CONCLUSIONS}

Provision of security and public order is a vital but also a very difficult task. Prevention and anti-riot units of police forces constitute an important element of the law enforcement system. The present shape of prevention in the Polish Police Forces is an outcome of many decades of evolution which occurred alongside political, social and economic changes. With time organisational structures, rules of conduct, functioning and even headcount has been adjusted to meet current needs and assure efficiency of performed tasks and duties. The deployment of preventive forces has always reflected the administrative division of the country and responded to distribution of possible threats to assure speedy and efficient intervention whenever necessary.

Contemporary anti-riot prevention units are well-trained and well-equipped to be at the service of citizens. It should be noticed, however, that threats change and evolve with time, therefore comprehensive theoretical and practical training of police officers is critical to keep up with the changing reality. Insufficient knowledge or lack of necessary skills may lead to lowering of standards in the service which may in turn increase the level of threat to the internal security and public order. Taking into account the nature of contemporary threats, it is estimated that the role of special task ant-riot units in providing security and public order will continue to grow along volatile nature of current security environment. The formation should constantly adapt itself to the changing reality in order to maintain efficiency of operations, adjust its educational programmes and modernize equipment. Another important aspect is maintaining close cooperation with other agencies performing tasks related to security and public order.

\section{REFERENCES}

Czapska,, J. and Wójcikiewicz, J. (1999). Policja $w$ spoleczeństwie obywatelskim. Kraków: Wolters Kluwer Polska SA, pp.17. 
Jałoszyński, K. and Zalewski, S. (2009). Organy administracji rzadowej wobec zagrożeń terrorystycznych. Stużby specjalne wobec terroryzmu. Bielsko-Biała: Wyższa Szkoła Administracji, pp.44.

Majer, P. (2004). Milicja Obywatelska 1944-1957. Olsztyn: UW-M, pp.20, 234-235.

Marszałek, P. (2009). Prawo Policji Państwowej w II Rzeczpospolitej 19151945. Toruń: Adam Marszałek, pp.8.

Mączyński, M. (1997). Policja Państwowa w II Rzeczypospolitej. Kraków: Księgarnia Akademicka, pp.94.

Misiuk, A. (1998). Policja Państwowa 1919 - 1939. Warszawa: PWN, pp.15,20,21,24,181,206

Misiuk, A. (2008). Historia Policji w Polsce od X wieku do wspótczesności. Warszawa, pp.96-112, 172.

Socha, R., Letkiewicz, A. and Guła, P. (2010). Policyjne oddziały i pododdziały zwarte w Polsce. Historia i teraźniejszość. Szczytno: The Police Academy in Szczytno, pp.68-70.

Sprengel, B. (2011). Policja Państwowa, a organy władzy publicznej w polityce ochrony bezpieczeństwa wewnętrznego w Polsce $w$ latach 1918-1938. Toruń: PWN, pp.250-260. 